\title{
Aspects of Quality Tools on Total Quality Management
}

\author{
Kairong Liang \\ SAIC GM Wuling Automobile Co., Ltd. \\ Add: 18 Hexi Road, Liuzhou city, Guangxi 545007, China \\ E-mail: kairong.liang@sgmw.com.cn
}

\begin{abstract}
The use of Quality Tools to improve both product and process quality is currently a common practice. However, there are two schools of thought on the use of Quality Tools, namely, statistical quality tools or non-statistical quality tools. The purpose of this article is to literature review the pros of implementing these quality tools; review the issues related to the implementation of such tools and finally understand the role of such tools in the framework of TQM.
\end{abstract}

Keywords: Quality tools, Total quality management, Statistical quality tools, Error proofing (Poke-Yoke)

\section{Introduction}

Quality plays an important role in an organization overall strategy. The biggest challenge for an International company in gaining global market share is to first understand the global customer. Most companies select to apply some quality tools to improve the quality of their products. But there are some arguments between the statistical quality tools and non-statistical tools. It was said that statistical tools have been redundant in the wake of non-statistical quality tools and techniques, such as source inspection and Poke-Yoke.

\section{Literature Review}

\subsection{Development of quality management system}

Despite the fact that quality management systems have developed over the century, there are still some different aspect to the quality management. If we want to get a clear context of quality management, it is necessary to review the development of TQM.

Dale (2003) has divided the evolution of quality management into four stages. Reference Figure 1, the four stages are inspection, quality control, and quality assurance and total quality management.

In different stage, there are some quality management gurus contribute their wisdom to the body knowledge of quality management.

Some most important guru's follows the evolutions of TQM are

Americans: Deming, Juran, Feigenbaum, Peters, Crosby

Japanese: Ishikawa, Taguchi, Shingo

Table 1, provides a comparative analysis of the Quality Gurus and their schools of thought on different viewpoints.

\subsection{Theories about the TQM}

\subsubsection{Understanding what is quality}

There are some different understandings about the quality. The general understanding is that quality is the process of inspection to detect and capture defects. The BS standard defines quality as the process of producing the product to meet the technical requirements. In TQM, quality is defined as customer satisfaction.

Due to different understandings of quality systems, there are different strategies for quality tools. For instance GM believes "Quality is what the customer perceives to be acceptable to achieve his/her enthusiasm". Quality Motto, "Quality Creates Customer Enthusiasm" drives this message down to the production line by ensuring "Do not accept build ship a defect." To support this motto, GM uses Shingo's Poke-yoke methodology with added resource inspection to improve the quality. (Source from the GM documentation)

\subsubsection{What is TQM?}

Juran (1998 p. 372) defined the concept of Total Quality Management( TQM) as a set of management processes and systems that create delighted customers through empowered employees, leading to higher revenue and lower cost. Ross and Perry (1999 p.1) describe total quality management (TQM) as the integration of all functions and processes within an organization in order to achieve continuous improvement of the quality of goods and 
services. The goal is "customer satisfaction".

\subsection{The argument about the statistical tools}

Table 1 shows that statistical methods are widely used practice for analyzing the data collected at inspection at the end of process. Confirming that the oldest and most widely knows of the quality process control methods was based on statistical techniques. Most of the quality management gurus are statisticians.

From Table 1, it is evident that the different gurus had different opinions and some cases even have opposing opinion, namely, the argument between non-statisticians and statisticians.

With non-statistical quality technologies development, the statistical quality methods have come to face several challenges. The main challenge comes from the production way change. As we know that Toyota has developed a new production system - Toyota Product System (TPS) (Womack $1990 \mathrm{p} \mathrm{55).} \mathrm{TPS} \mathrm{not} \mathrm{only} \mathrm{deploys}$ Just-in-Time but also changed the way of quality management. Taiichi Ohno (1988 p. 32) designed Andon system to support the quality on the production line; Shingo Shigeo developed a non-statistical quality management tools: Poke-yoke systems and resource inspection. Poke-Yoke System: Set-up devices or inspection techniques that assure that set-up is done correctly; i.e. produces $100 \%$ good parts from the first piece on (Shingo, 1986 p. v). Base on the opinion of Shingo, there are four arguments about the statistical tools. They are as follows,

Quality target: In statistical quality control, the quality target is acceptable quality level (AQL). AQL means defects still exist. The target is unacceptable by the customers' satisfaction. Target actually is based on customer satisfaction levels!

Quality cost: Unavoidable cost of statistical methods is for the inspection.)

Quality process: The process of statistical methods need long time for the information feedback.

Result of analysis: It was hard to be understood the context of what is going on or the nature of the problem. So Taiichi Ohno said "data is of course important in manufacturing, but I place the greatest emphasis on facts." (Liker 2004 p.221)

Based on the information alone, it is evident that there are two schools of thoughts at the use of statistical tools for quality management. And Juran (1998 p.98) also said that it was risk in taking a tool-oriented approach to quality instead of a problem oriented or results-oriented approach.

\section{Review the issues of implementation of quality tools}

From the review above, is it really that the statistical tools have been made redundant? To answer this question, it is necessary to view it in system perspective. It is necessary to understand what kinds of tools are used in the quality management and what relation between the tools is.

\subsection{The quality tools and the relation between the tools}

The quality 75 is a good brochure which introduces the most useful quality tools. The Table "PDCA, DMAIC and Tools" gives us a snapshot of the tools, Table 2. (Bicheno 2002 p.4)

In the Table 2, it is known that not only the non-statistical tools but also the statistical tools are used in the quality management, and the tools are cataloged into different volumes by the structure of PDCA and DMAIC. This implies that the tools are used in the different phases of the PDCA and DMAIC process. The different tools work together to support the quality improvement.

Bicheno (2002 p.6) also use a Figurer to show the relation between the quality tools. (See Figure. 2) In the Figurer, it is seen that the tools combine together to form a building of quality management. The findings if the gurus are the foundation on which the base tools, standards, 7 wastes and 6 new tools become the different levels of the building block. 2 System, 27 general tools and 8 service tools form the three main pillars of the building. And the 6 Sigma is the roof of the building. In this concept, put away any tools will cause the quality management building to fall.

\section{$3.2 \mathrm{~A}$ review of the problems in the implementation of tools}

The importance of using quality tools in an organization is a well understood requirement. However, that doesn't imply that all quality tools used to be deployed for it to be effective. It is also important to realize that we choose and implement the tools. That will be significant obstacles and difficulties.

Dale describes about the difficulties related to the deployment of tools and techniques. In this paper, he also provides certain tools to use to anticipate development issue, one of the tools to anticipate the any problems in the implementation of the tools. The tool is Fishbone Diagram. (Bicheno 2002 p.31) (See Figure. 3) 
The problems which are anticipated in the implementation of tools will be discussed in follow:

Leadership support - Quality management is an activity of the company. If the leadership doesn't understand the roles and functions of the quality tools, the implementation of tools will become very difficulty thing.

User understanding- Oakland and Porter (1995 p.197) said the people who work on the processes decided the effective use of the quality tools.

System compatibility - Different systems use different tools. For example Toyota product system chooses the tools of Zero Quality Control.

Initial investment - Implementation of tools require an increase in investment.

Integration - Some tools need to integrate together.

Discipline and application -Without the Discipline and application, tools will become decoration of the company.

Level of complexity - The complexity of the tools will increase the difficulties of implementation.

Culture conflict - Different companies' culture will affect the effective of the implementation.

Quality atmosphere - Lack of a quality atmosphere will make it hard to push tools application.

Organization structure - Some tools implementation face the challenge of re-organization.

\subsection{Solution for the problems}

In terms of the analysis, it is clear that implementation of the quality tools still face many challenges. If we can understand the problem, we can develop a solution for the problem.

For instance, relative to the problem of initial investment of the quality tools, we can use the Matrix Chart to analyze and how to choose the tools to improve quality. (Figure. 4)

In this case, there are four tools want to be implement. But there aren't enough budgets to invest on all of the tools. Through analysis, it is known that Tool 1 has high effect in quality improvement and low cost to implement. That should be good choice to prioritize the Tool 1 implementation.

\section{Discussion}

What is the good attitude to the implementation the quality tools. It is necessary to understand the TQM and the framework. We should have systemic perspective to TQM implementation, not just one or two quality management tools.

\subsection{TQM Framework and model}

It is necessary to understand the TQM framework and the model in implementation of the quality tools. In Dale's (2003 p.77) the TQM framework, it is known that the foundation of TQM is Organizing, Systems and techniques, Culture change and Measurement and feedback. (See Figure. 5)

\subsection{The role of quality tools in TQM}

Quality tools pay important roles in the quality improvement process. Juran said that the quality tools should be integrated with a structured quality improvement process. Different tools have different functions in the quality improvement process. Juran designed a chart to illustrate the roles of tools in the quality improvement process. (See Table 3)

Dale also defined the roles for tools and techniques in quality management. The main roles include:
a) Summarizing data and organizing its presentation
b) Data-collection and structuring ideas
c) Identifying relationship
d) Discovering and understanding a problem
e) Implementing action
f) Finding and removing the causes of the problem
g) Selecting problems for improvement and assisting with the setting of priorities
h) Planning
i) Performance measurement and capability assessment

(Table 4) 
Through analysis, it is found that the statistical tools still play important roles in the quality improvement.

\subsection{The process for implementation of the quality tools}

Dale (2003 p.84) has given some useful tips about how to implement quality in the section of Systems and techniques. It is summarized in a process chart (See Figure. 6).

Systems and techniques as one pillar of the framework of TQM need to setup the quality management system by using the quality management tools and techniques. The process should be the good approach to implement the quality tools in quality improvement.

Dale (2003, p.309) also suggested that there are two factors about the tools which we should remember:

Without a strategy and plan, the implementation of any tool and technique in isolation will not get the long-term benefit

There is no one tool or technique which is more important than others. Not only the non-statistical tools but also the statistical tools play important role at some point of the quality improvement process.

\section{Conclusion}

From this literature review, it is evident that we should have a system perspective to view the quality tools and methods in the quality improvement process. Quality tool is an important pillar of the TQM framework. Despite different gurus have different opinion of quality management, we still can choose the quality tools base the fact that on understanding the roles of the important tools and identify the situation of the implementation environment.

Before we apply the tools in our process, we should identify the problems and difficulties of implementation. We should develop solutions for the anticipate problem and establish the right approach to implement the quality tools.

We should throw away the prejudgment of the quality tools and further study and combine the theories with practice in our business. We will achieve Crosby's "quality free”. (Bicheno 2002 p.12)

\section{References}

Bicheno, J. (2002). The Quality 75: Towards Six Sigma Performance in Service and Manufacturing. PICSIE Book.

Dale, Barrie G. (2003). Managing quality. - 4th Ed. Oxford: Blackwell Publishers.

Juran, J.M. and A. B. Godfrey, (1998). Juran's quality handbook. 5th Ed. New York: McGraw-Hill.

Liker, J. K., (2004). The Toyota Way: 14 Management Principles from the World's Greatest Manufacturer. New York: McGraw-Hill

Monden Yasuhiro (1998). Toyota production systems. 3rd Ed. London: Chapman \& Hall.

Oakland, J. S. and L. J. Porter. (1995). Total Quality Management, text with cases. Oxford: Butterworth-Heinemann.

Ross and Perry. (1999). Quality management text cases and readings London: St. Lucie Press.

Shingo, Shigeo (1986). Zero Quality Control: Source Inspection and the Poka-yoke System. Cambridge: Productivity Press.

Shingo, Shigeo. (1989). A study of the Toyota production system from an industrial engineering viewpoint. Portland: Productivity Press.

Slack, N., et. Al. (2004). Operations management. 4th Ed. Edinburgh: Pearson Education Limited.

Taiichi Ohno (1988). Toyota Production System: beyond large-scale production. Cambridge: Productivity Press Womack J., et. Al. (1990). The Machine That Changed the World. New York: Rawson Associates. 
Table 1. Comparing the leading voices in the TQM

(Source from: Dale 2003 p.51-64, Slack 2004 p.721, Bicheno 2002 p.7-23)

\begin{tabular}{|c|c|c|c|c|c|c|}
\hline Items & Deming & Juran & Feigenbaum & Ishikawa & Shingo & Crosby \\
\hline Concept & $\begin{array}{l}\text {-Profound } \\
\text { Knowledge }\end{array}$ & $\begin{array}{l}\text {-meeting the } \\
\text { customer's needs }\end{array}$ & $\begin{array}{l}\text {-managing a } \\
\text { business }\end{array}$ & $\begin{array}{l}\text {-Total quality } \\
\text { viewpoint }\end{array}$ & $\begin{array}{l}\text {-zero quality } \\
\text { control }\end{array}$ & -zero defects \\
\hline Principle & -Deming 14 points & $\begin{array}{l}\text {-Most quality } \\
\text { problems come } \\
\text { from management }\end{array}$ & $\begin{array}{l}\text {-Customer- } \\
\text { oriented quality } \\
\text { management }\end{array}$ & $\begin{array}{l}\text {-Quality } \\
\text { improvement is } \\
\text { more important } \\
\text { than specialists }\end{array}$ & $\begin{array}{l}\text {-prevent errors } \\
\text { from becoming } \\
\text { defects }\end{array}$ & -Four absolutes \\
\hline Human Facts & -People are valued & $\begin{array}{l}\text {-high level } \\
\text { management } \\
\text {-specialists }\end{array}$ & $\begin{array}{l}\text {-need for worker } \\
\text { involvement } \\
\text {-identify the } \\
\text { human issues }\end{array}$ & $\begin{array}{l}\text {-Human side of } \\
\text { quality }\end{array}$ & -Full participation & $\begin{array}{l}\text {-quality of } \\
\text { leadership }\end{array}$ \\
\hline $\begin{array}{l}\text { Tools and } \\
\text { Methods }\end{array}$ & $\begin{array}{l}\text {-Using statistics } \\
7 \text { point action plan }\end{array}$ & $\begin{array}{l}\text {-Using statistics } \\
\text { Tools are } \\
\text { important } \\
\text {-Quality Planning } \\
\text {-Quality control } \\
\text {-Quality } \\
\text { Improvement }\end{array}$ & $\begin{array}{l}\text {-methods and tools } \\
\text { are not all } \\
\text { TQC }\end{array}$ & $\begin{array}{l}-7 \text { Tools } \\
\text {-Quality Circles }\end{array}$ & $\begin{array}{l}\text {-Poka-Yoke } \\
\text { devices } \\
\text {-source inspection } \\
\text {-Rejects statistical } \\
\text { methods }\end{array}$ & $\begin{array}{l}\text {-Crosby } 14 \text { step } \\
\text { plan }\end{array}$ \\
\hline Strengths & $\begin{array}{l}\text {-Identifies stages } \\
\text {-Stresses } \\
\text { management } \\
\text {-Leadership } \\
\text {-Statistical } \\
\text {-Different JP\& } \\
\text { USA }\end{array}$ & $\begin{array}{l}\text {-Move away from } \\
\text { hype and slogans } \\
\text {-Stresses customer } \\
\text {-Management } \\
\text { involvement }\end{array}$ & $\begin{array}{l}\text {-Quality control } \\
\text {-Importance of } \\
\text { management } \\
\text {-Systems thinking } \\
\text {-Full participation }\end{array}$ & $\begin{array}{l}\text {-Design quality } \\
\text {-Quality is social } \\
\text { issue } \\
\text {-Engineers than } \\
\text { statistician } \\
\text {-Process control }\end{array}$ & $\begin{array}{l}\text { - Full participation } \\
\text {-Zero defect } \\
\text {-Resource } \\
\text { inspection }\end{array}$ & $\begin{array}{l}\text {-Methods easy to } \\
\text { follow } \\
\text {-Worker } \\
\text { participation }\end{array}$ \\
\hline Weakness & $\begin{array}{l}\text {-Action plan are } \\
\text { vague } \\
\text {-Idiosyncratic } \\
\text { leadership and } \\
\text { motivation } \\
\text {-Not political or } \\
\text { coercive treat } \\
\text { situations }\end{array}$ & $\begin{array}{l}\text {-Not relate other } \\
\text { work to leadership } \\
\text {-Rejecting bottom- } \\
\text { up initiatives } \\
\text {-Weak in human } \\
\text { dimension }\end{array}$ & $\begin{array}{l}\text {-Does not } \\
\text { discriminate } \\
\text { quality context } \\
\text {-Does not bring } \\
\text { together theories } \\
\text { into one coherent } \\
\text { whole. }\end{array}$ & $\begin{array}{l}\text {-Methods seen as } \\
\text { simplistic } \\
\text {-Not deal } \\
\text { adequately with } \\
\text { moving quality } \\
\text { circles from ideas } \\
\text { to action }\end{array}$ & $\begin{array}{l}\text {-Organization } \\
\text { change } \\
\text {-Culture conflict }\end{array}$ & $\begin{array}{l}\text {-Zero defects seen } \\
\text { as risk avoidance } \\
\text {-Insufficient stress } \\
\text { given to statistical } \\
\text { methods }\end{array}$ \\
\hline
\end{tabular}

Table 2. PDCA, DMAIC and Tools (Bicheno 2002 p 4)

\begin{tabular}{|c|c|c|c|c|}
\hline Plan & Define & $\begin{array}{l}\text { What is the } \\
\text { Problem? }\end{array}$ & $\begin{array}{l}\text { Identify } \\
\text { Opportunities } \\
\text { Scope the } \\
\text { Project }\end{array}$ & $\begin{array}{l}\text { Benchmarking, QFD, Disruptive Tech, Hoshin, } \\
\text { FMEA, Serv Gaps, Pareto, Mapping, Importance } \\
\text { Performance, Market survey, NGT, Tree diagram, } \\
\text { Critical Path Analysis }\end{array}$ \\
\hline & $\begin{array}{l}\text { Measur } \\
\mathrm{e}\end{array}$ & $\begin{array}{l}\text { How are we } \\
\text { doing? }\end{array}$ & $\begin{array}{l}\text { Analyze the } \\
\text { Process } \\
\text { Define } \\
\text { Outcomes }\end{array}$ & $\begin{array}{l}7 \text { tools, DPMO, Data presentation, } 5 \text { Why, Process } \\
\text { Chain, Mot, Kano, } 6 \text { Honest Men, Supplier Parters, } \\
\text { Capability analysis, CoQ, Maps, Blueprints, } \\
\text { SERVQUAL }\end{array}$ \\
\hline Do & $\begin{array}{l}\text { Analysi } \\
\mathrm{s}\end{array}$ & What is wrong? & $\begin{array}{ll}\text { Identify Root } \\
\text { Causes }\end{array}$ & $\begin{array}{l}5 \text { Whys, FMEA, } 7 \text { tools, DOE, QFD, Matrix } \\
\text { analysis, Shainin, Gap analysis, Cusum, } \\
\text { Benchmarking, Zone of tolerance }\end{array}$ \\
\hline $\begin{array}{l}\text { Chec } \\
k\end{array}$ & Improve & Fix it & $\begin{array}{l}\text { Priorities } \\
\text { Refine } \\
\text { Implement }\end{array}$ & $\begin{array}{l}\text { QFD, Matrix analysis, Hoshin } \\
\text { QFD, Affinity, Contingency, FMEA } \\
\text { Force Field, Kaizen, Blitz } \\
\text { Critical Path, Single point lessons, Johari }\end{array}$ \\
\hline Act & Control & $\begin{array}{l}\text { Hold the gains. } \\
\text { Celebrate }\end{array}$ & $\begin{array}{l}\text { Measure } \\
\text { Outcomes } \\
\text { Acknowledge }\end{array}$ & $\begin{array}{l}\text { Control Charts and SPC, 5S standardization, DPMO, } \\
\text { Cusum, Cost of Quality, ISO 9001:2000, } \\
\text { Sustainability, Capability, } \\
\text { Supplier Partnerships }\end{array}$ \\
\hline
\end{tabular}


Table 3. The tools role in the Quality Improvement Process (Juran 1998 p.1577)

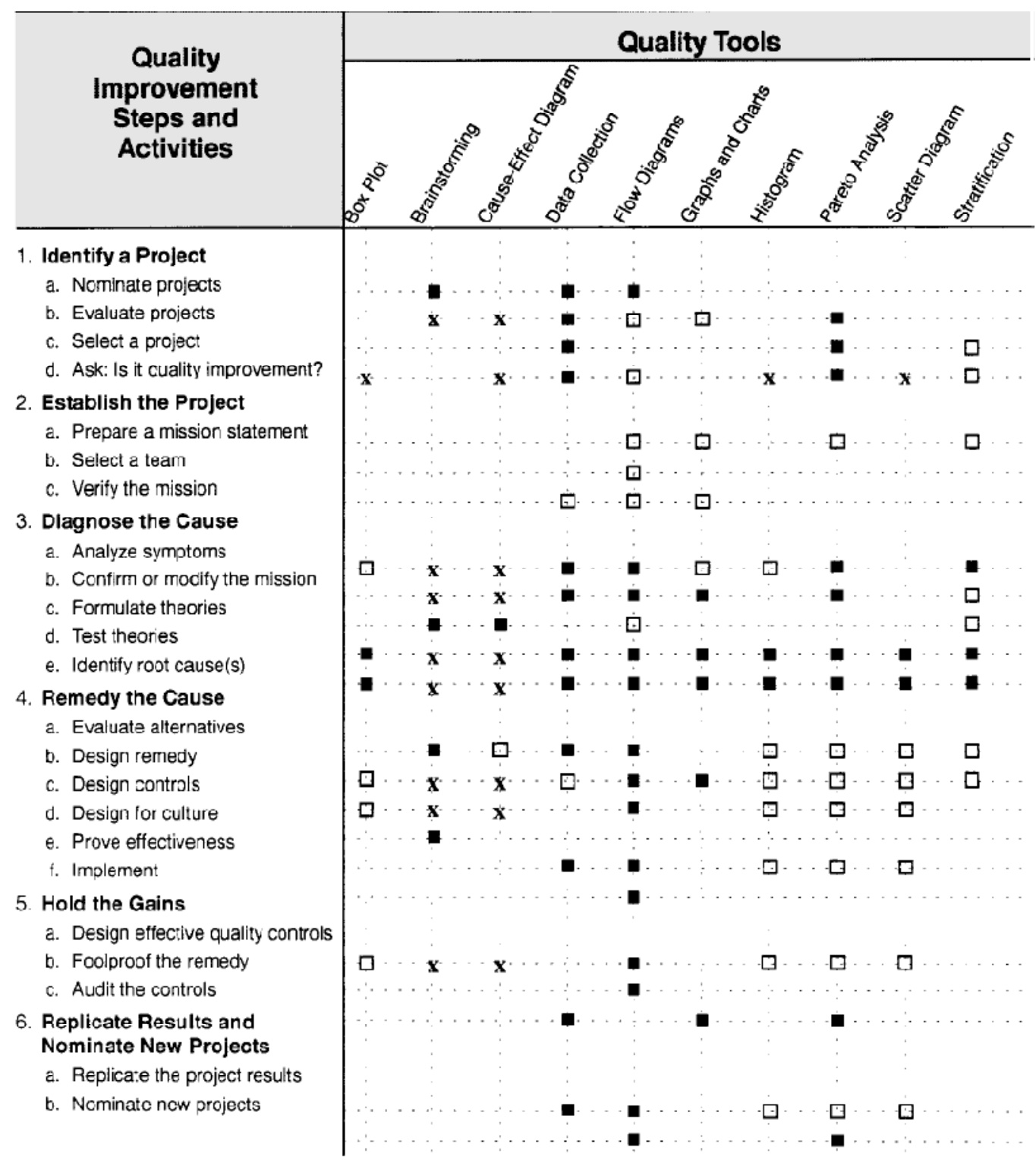


Table 4. The role of most popular quality tools

\begin{tabular}{|c|c|c|c|c|c|c|c|c|c|c|c|c|c|c|}
\hline Roles of QT & 01 & 02 & 03 & 04 & 05 & 06 & 07 & 08 & 09 & 10 & 11 & 12 & 13 & 14 \\
\hline Summarizing data & $\sqrt{ }$ & $\sqrt{ }$ & $\sqrt{ }$ & $\sqrt{ }$ & $\sqrt{ }$ & & & & & & & & & \\
\hline Data-collection & $\sqrt{ }$ & $\sqrt{ }$ & $\sqrt{ }$ & $\sqrt{ }$ & $\sqrt{ }$ & & & & & & & & & \\
\hline $\begin{array}{l}\text { Identifying } \\
\text { relationship }\end{array}$ & & $\sqrt{ }$ & & & & & & & $\sqrt{ }$ & & & $\sqrt{ }$ & $\sqrt{ }$ & \\
\hline $\begin{array}{l}\text { Discovering } \\
\text { problem }\end{array}$ & & $\sqrt{ }$ & & $\sqrt{ }$ & & & & $\sqrt{ }$ & & & & & $\sqrt{ }$ & $\sqrt{ }$ \\
\hline Setting of priorities & $\sqrt{ }$ & $\sqrt{ }$ & & $\sqrt{ }$ & & & $\sqrt{ }$ & & & & & $\sqrt{ }$ & & \\
\hline Planning & $\sqrt{ }$ & $\sqrt{ }$ & & & & & & & & & & & & \\
\hline $\begin{array}{l}\text { Performance } \\
\text { measurement } \\
\end{array}$ & $\sqrt{ }$ & $\sqrt{ }$ & & & $\sqrt{ }$ & & & & & $\sqrt{ }$ & $\sqrt{ }$ & $\sqrt{ }$ & & $\sqrt{ }$ \\
\hline $\begin{array}{l}\text { Tools No. } \\
\text { Statistical tools } \\
\text { Non-Statistical too }\end{array}$ & $\square$ & \multicolumn{7}{|c|}{ : 01-SPC 02-6 Sigma 03-Control Chart } & $\begin{array}{r}04- \\
\text { restio }\end{array}$ & OOE & \multicolumn{4}{|c|}{$\begin{array}{l}\text { 05-Process Capability } \\
\text { me } 08-5 \mathrm{~S} \text { (CANDO) }\end{array}$} \\
\hline $\begin{array}{l}\text { 09-5Whys } 10-7 \\
\text { 14-Source inspectio }\end{array}$ & Wastes & 11 & Poka & Toke & $12-1$ & le $\mathrm{D}$ & $\operatorname{ming}$ & Cycl & 13 & Caus & -and & Effect & Diag & rams \\
\hline
\end{tabular}

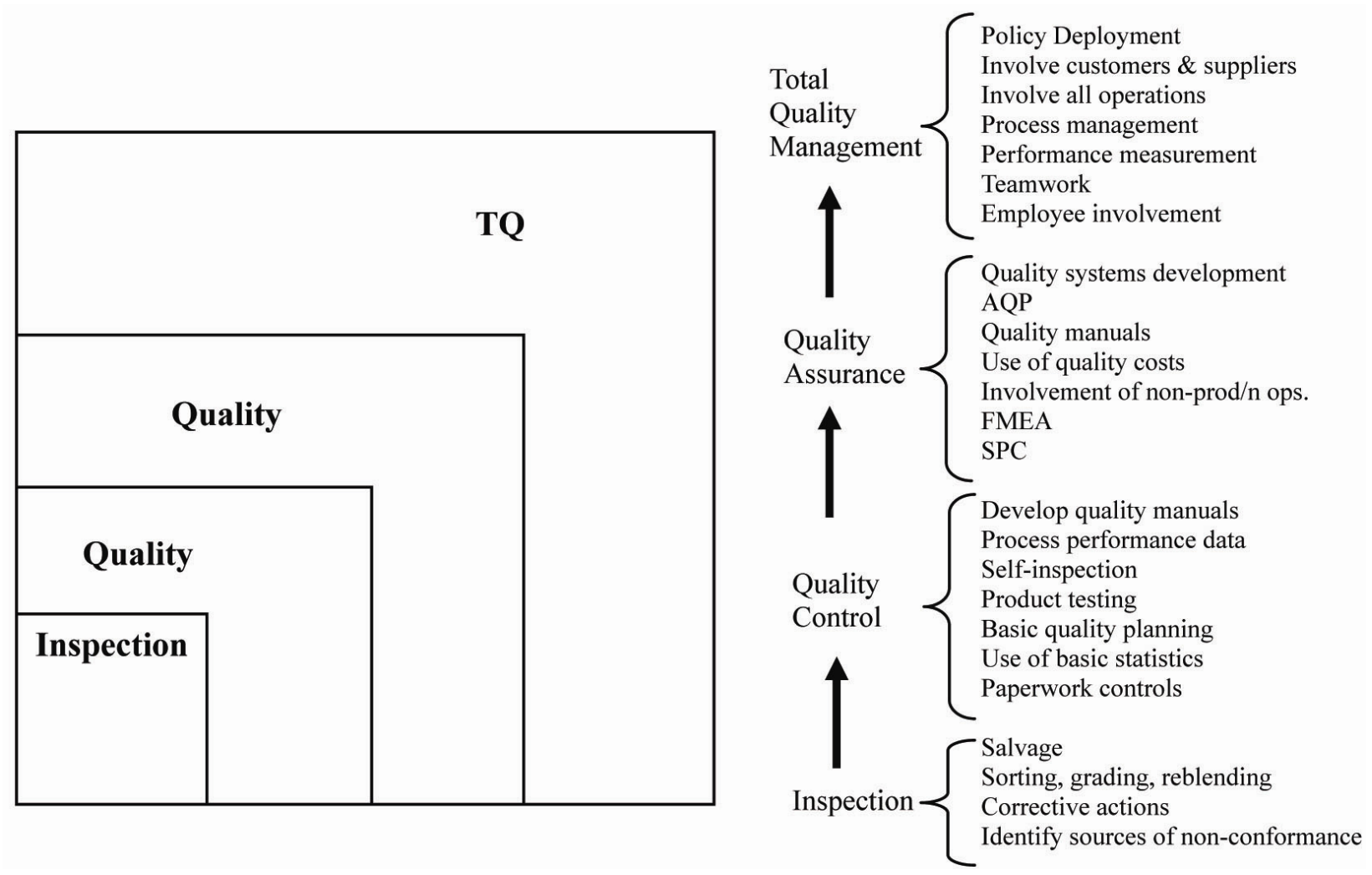

Figure 1. The four stages of evolution of quality management (Dale 1999 p21) 


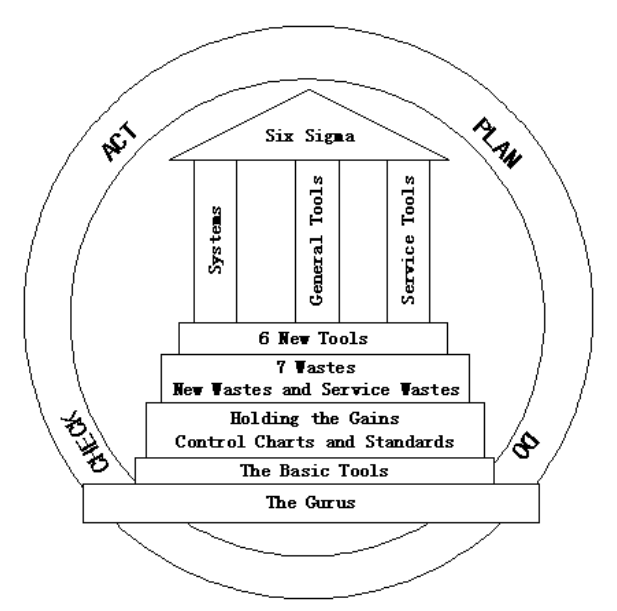

Figure 2. The quality control tools and techniques in service and manufacturing (Bicheno 2002 p6)

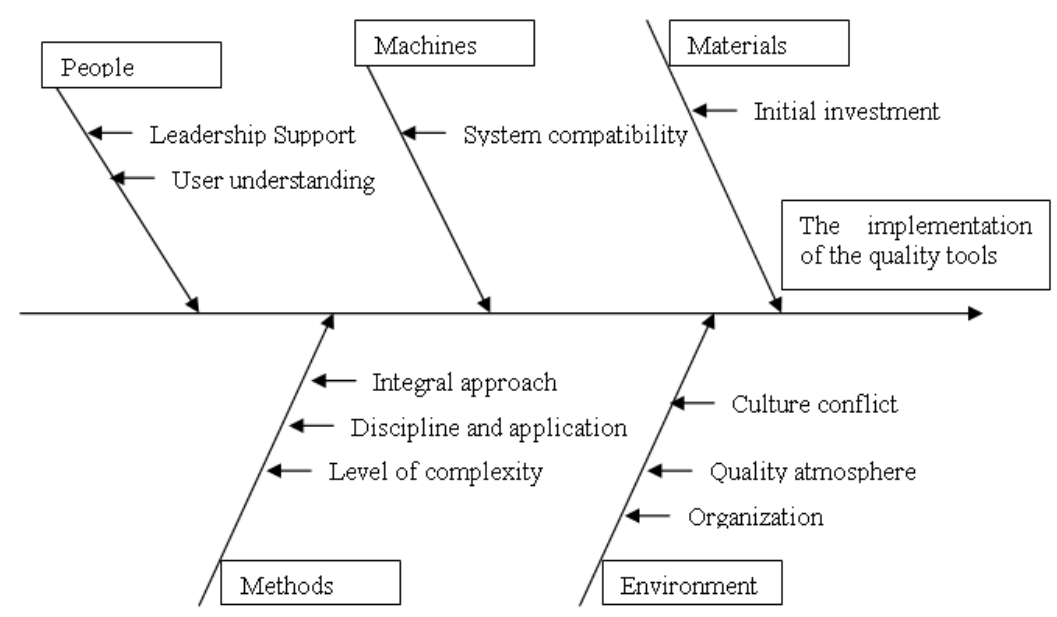

Figure 3. The problems for the implementation of quality tools

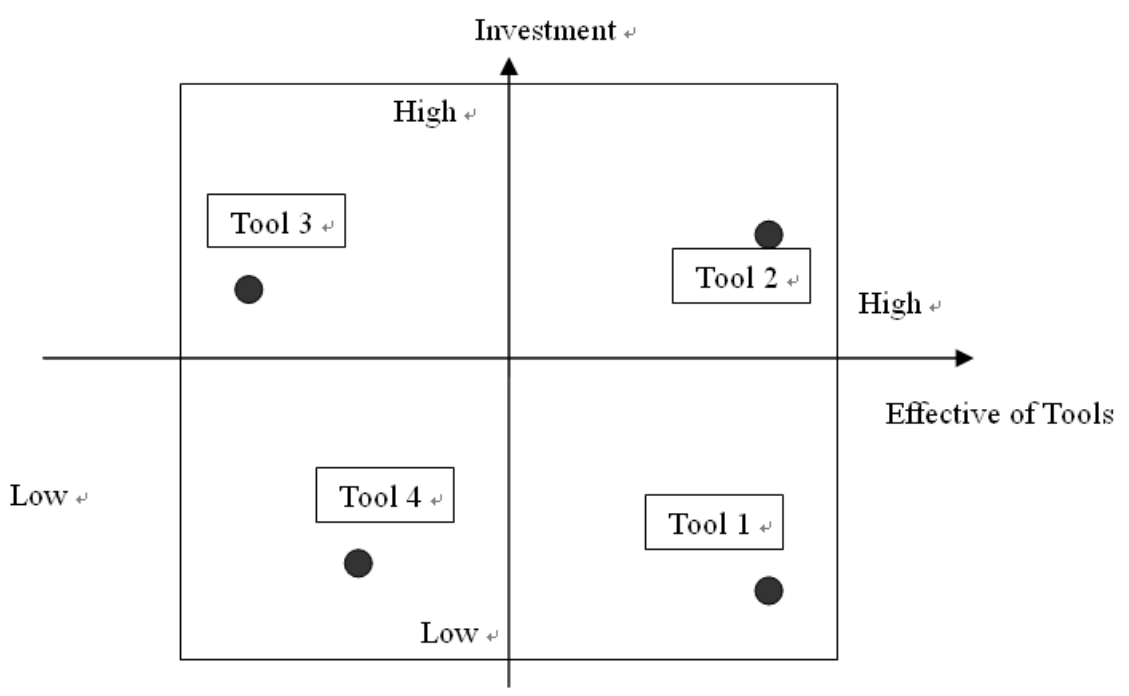

Figure 4. The matrix analysis 


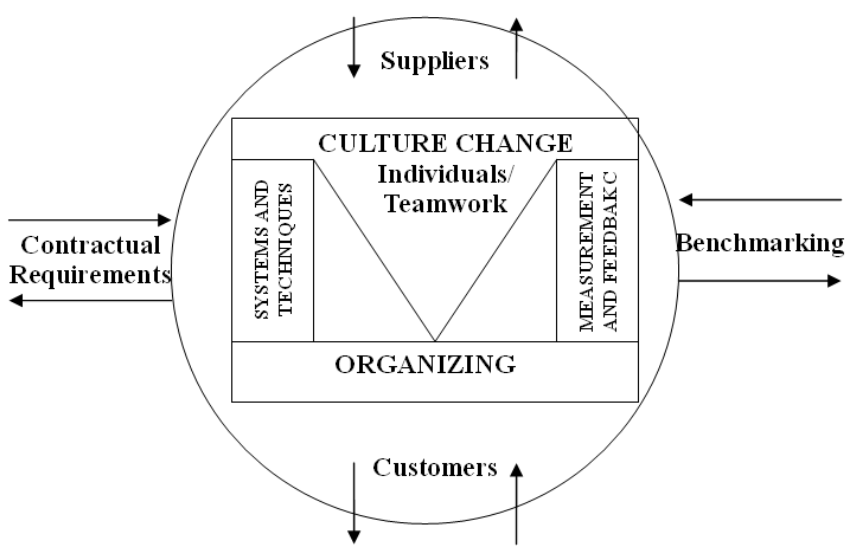

Figure 5. The TQM framework (Dale 2003 p.77)

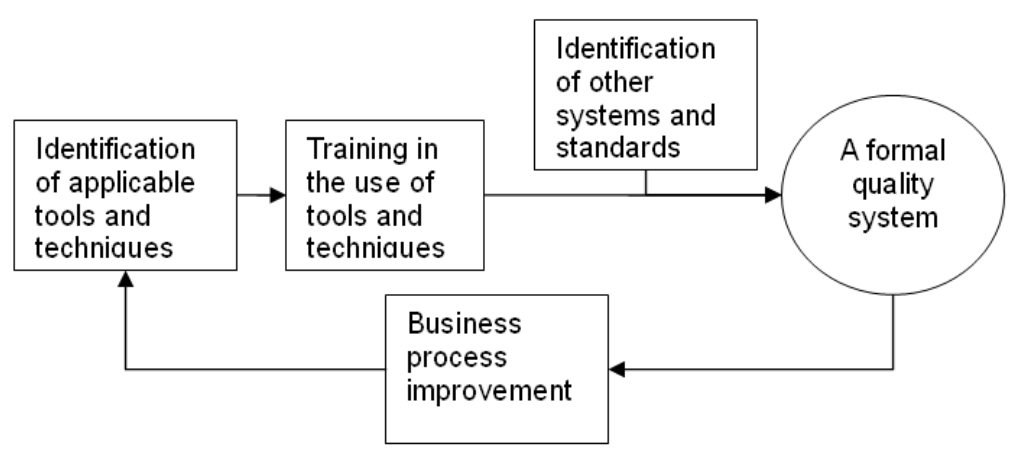

Figure 6 . The process of quality tools implementation 